\title{
Monitoring and Statistical Analysis of Formation of Organochlorine and Organobromine Compounds in Drinking Water of Different Water Intakes
}

\author{
Margarita Yu. Vozhdaeva ${ }^{1,2, *}$, Alfiya R. Kholova ${ }^{1}$, Igor A. Melnitskiy ${ }^{1}$, Ilya I. Beloliptsev ${ }^{3}$, Yulia S. Vozhdaeva ${ }^{4}$, \\ Evgeniy A. Kantor ${ }^{2}$ and Albert T. Lebedev ${ }^{5, *(1)}$
}

1 State Unitary Enterprise “Ufavodokanal”, Water Treatment Station, Rossiyskaya St. 157/2, Ufa 450098, Russia; al-pochta@mail.ru (A.R.K.); i_melnit@rambler.ru (I.A.M.)

2 Department of Petrochemistry and Chemical Technology, Department of Physics, Ufa State Petroleum Technical University, Kosmonavtov St. 1, Ufa 450000, Russia; evgkantor@mail.ru

3 Department of Mathematics and Computer Science, Ufa Branch, Financial University, Mustaia Karima St. 69/1, Ufa 450015, Russia; IIBeloliptsev@fa.ru

4 Department of Mechanics and Mathematics, St. Petersburg State University, Universitetskaia Emb. 7/9, Saint-Petersburg 199034, Russia; uni_vozhd@mail.ru

5 Organic Chemistry Department, Lomonosov Moscow State University, Leninskie Gori 1/3, Moscow 119991, Russia

* Correspondence: vozhdaeva@mail.ru (M.Y.V.); a.lebedev@org.chem.msu.ru (A.T.L.)

Citation: Vozhdaeva, M.Y.; Kholova, A.R.; Melnitskiy, I.A.; Beloliptsev, I.I.; Vozhdaeva, Y.S.; Kantor, E.A.; Lebedev, A.T. Monitoring and Statistical Analysis of Formation of Organochlorine and Organobromine Compounds in Drinking Water of Different Water Intakes. Molecules 2021, 26, 1852. https://doi.org/ $10.3390 /$ molecules 26071852

Academic Editor:

Mohammed Baalousha

Received: 16 February 2021

Accepted: 21 March 2021

Published: 25 March 2021

Publisher's Note: MDPI stays neutral with regard to jurisdictional claims in published maps and institutional affiliations.

Copyright: (c) 2021 by the authors. Licensee MDPI, Basel, Switzerland. This article is an open access article distributed under the terms and conditions of the Creative Commons Attribution (CC BY) license (https:/ / creativecommons.org/licenses/by/ $4.0 /)$.

\begin{abstract}
The main drawback of drinking water chlorination involves the formation of quite hazardous disinfection by-products (DBPs), represented mainly by halogenated species. Based on the authors' monitoring data since 2002, the prevalence of chlorine over bromine in the composition of volatile DBPs was shown for the drinking water in Ufa (Russia). However, the situation was completely reversed in the case of semi-volatile DBPs. The principal goal of the present study involved rationalization of the results of the long-term monitoring. Gas chromatography-mass spectrometry (GC-MS) was used for the qualitative and quantitative analysis of volatile DBPs. Identification of semi-volatile compounds was carried out with GC-MS, while gas chromatography with an atomic emission detector (GC-AED) was used for their quantification. A significant contribution of oxygen to the composition of semi-volatile compounds proves the decisive role of the dissolved organic matter oxidative destructive processes. Statistical analysis revealed notable linear correlations for trihalomethane and haloacetic acid formation vs. chlorine dose. On the contrary, halogenated semivolatile products do not demonstrate any correlations with the water quality parameters or chlorine dose. Principal component analysis (PCA) placed them into separate groups. The results allow for proposing that formation of the organohalogenated species involved the fast penetration of bromine into the humic matter molecules and, further, their oxidative destruction by active chlorine.
\end{abstract}

Keywords: brominated DBP; chlorinated DBP; THM; HAA; SVOC; GC-MS; aqueous chlorination

\section{Introduction}

The quality of drinking water dramatically influences human health. Drinking water should satisfy the required hygienic standards, and disinfection represents one of the most important stages of water preparation and the most efficient tool to prevent diseases spreading through water [1]. Elimination of pathogenic microorganisms during water preparation started at the beginning of the 20th century and considerably decreased the threat of these diseases [2]. Chlorination remains the most widespread method of water disinfection all over the world. A critical advantage of chlorination over alternative methods of disinfection involves its prolonged activity, which is crucial for big cities with extended water distribution networks, while its main drawback is the formation of numerous disinfection by-products (DBPs). The study of the formation of trihalomethanes (THMs) 
and haloacetic acids (HAAs) as the major DBPs started in the 1970s [3-9]. Nevertheless, organohalogenated compounds of a higher mass (aldehydes, ketones, acids, acetonitriles, phenols, etc.) may also be quite hazardous [10-14]. Over 700 DBPs are currently known [15], constituting only half of the total of organic chlorine. Natural dissolved organic matter (humic and fulvic acids, phenols, amines, products of algal metabolism) is the principal precursor of DBPs [16-22]. Intensive anthropogenic impacts on drinking water sources lead to the inhibition of natural water self-purification processes. It may be accompanied by an increase in the abundance and assortment of phytoplankton and aquatic plants, resulting in humification [23]. Wastage of a notable portion of the dissolved oxygen on the oxidation of that additional organic matter induces an oxygen deficit and intensification of eutrophication. These changes lead to corresponding changes in the qualitative and quantitative composition of the chlorination by-products in drinking water. Anthropogenic impacts have an additional consequence. More and more industrial products appear in natural water and react with disinfecting agents at water treatment stations, producing novel DBPs [24-29].

Peculiarities of the aquatic chlorination depending on the characteristics of humic matter have attracted significant attention from the scientific community [30-34]. Thus, it was shown [32] that hydrophobic fractions (mostly humic acids of soil origin) with molecular masses over $500 \mathrm{Da}$ form halogenated products in significantly higher quantities than hydrophilic fractions (aquatic fulvic acids) with molecular masses below $500 \mathrm{Da}$. High levels of fulvic acids in dissolved organic matter (DOM) results in more brominated than chlorinated THM during aquatic chlorination [8]. Seasonal changes in the composition of DOM may lead to notable changes in the composition of DBPs [6,17], inspiring an active search for efficient methods of elimination of fulvic and humic acids from water as the main precursors of DBPs [35-38].

Bromide anions, being natural water components, interact with "active chlorine" and, depending on $\mathrm{pH}$, form hypobromic acid $(\mathrm{HOBr})$ and/or corresponding hypobromite anions $\left(\mathrm{OBr}^{-}\right)[39,40]$. Both species readily react with dissolved organic compounds. Moreover, $\mathrm{HBrO} / \mathrm{BrO}^{-}$is significantly more reactive towards DOM $\left(k_{a p p}=1.6 \times 10^{6}\right.$ $\left.\mathrm{M}^{-1} \mathrm{~s}^{-1}\right)$ than $\mathrm{HClO} / \mathrm{ClO}^{-}\left(k_{a p p}=41 \mathrm{M}^{-1} \mathrm{~s}^{-1}\right)$ [41]. Interestingly, THM levels increase in the presence of ppb levels of bromides and ppm levels of chlorides during aqueous chlorination of sugars [42]. The presence of bromides below $100 \mathrm{ppb}$ results in their complete disappearance and formation of the corresponding brominated DBPs. Some earlier publications deal with studies of aqueous chlorination of water enriched with technogenic impurities, ions of iron and bromide $[43,44]$.

It is worth mentioning that disinfecting agents themselves may be treated as a source of bromides. Thus, phenol was used as a trap in experiments on aquatic chlorination in deionized water without even traces of bromides [45]. Nevertheless, reactions with aqueous chlorine used to produce drinking water resulted in the formation of bromodichloro-, dibromochloro- and tribomophenol, together with the expected trichlorophenol, demonstrating the presence of brominating agents in the aqueous chlorine. The reason involves the fact that $\mathrm{NaBr}$ is a natural impurity in $\mathrm{NaCl}$ used in the production of industrial chlorinating reagents based on active chlorine, e.g., sodium hypochlorite. Since the reaction rate of hypobromic acid with aromatic species is significantly higher in comparison with hypochloric acid [41], even traces of bromine in technical chlorinating reagents may result in notable levels of the corresponding brominated DBPs [46,47].

The formation of organobromines and their higher impact than that of the corresponding organochlorines $[7,14,48-50]$ require conducting targeted monitoring with quantification of the known ones and non-targeted screening of all types of these compounds to identify novel ones. Quite often, quantification of the most toxic individual organobromines is accompanied by the estimation of the overall content of brominated compounds, similarly to other integrated parameters. These parameters are quite important for the express testing of the safety of water. The following indices are the most demanded nowadays: total organic carbon (TOC), dissolved organic carbon (DOC), biodegradable dissolved organic car- 
bon (BDOC), ultraviolet absorption $\left(\mathrm{A}_{254}\right)$, specific ultraviolet absorption (SUVA $=\mathrm{A}_{254} / \mathrm{TOC}$ ), dissolved organic nitrogen (DON) and total organic halogen (TOX) [51-54]. An alternative approach involves measuring the total content of organohalides (chlorides, bromides, iodides) by ion chromatography after complete sample destruction [55-57]. These integral indices are called total organic bromine (TOBr), total organic chlorine (TOCl) and total organic iodine (TOI) and represent constituents of TOX. It is worth emphasizing that that indices estimate the value of extractable halogenated DBPs from water with organic solvents, including volatile, semi-volatile and non-volatile compounds. All of them are rather hazardous. Volatile and semi-volatile species are highly biopermeable. They notably decrease the organoleptic properties of drinking water. Many of them are regulated all over the world. Higher-mass non-volatile DBPs may also lead to volatile and semi-volatile species while degrading. Moreover, they can also be harmful for humans, while their structures and properties are studied much less than those of the more volatile species. Therefore, to understand the pathways of the aqueous chlorination of natural water containing DOM, to calculate the balance of the addition of disinfecting agents, and to produce drinking water of better quality, it is necessary to monitor as many individual DBPs as possible, taking into account their precursors and mechanisms of their formation and transformation.

To differentiate the types of DBP in everyday activity of Ufavodokanal-a water treatment station in Ufa (Russia) - the following integrated indices of water quality were developed and introduced into practice: technogenic organic carbon ( $\mathrm{TgOC})$, technogenic organic chlorine $(\mathrm{TgOCl})$, technogenic organic bromine $(\mathrm{TgOBr})$ and technogenic organic oxygen ( $\mathrm{TgOO}$ ) in semi-volatile organic compounds (SVOCs) with boiling points in the range of $150-500{ }^{\circ} \mathrm{C}$, isolated from water by liquid-liquid extraction [58].

The present study covers the results of long-term monitoring of numerous regulated volatile DBPs, including trihalometanes (THMs) and haloacetic acids (HAAs), as well as principal halogenated semi-volatile organic compounds in water intakes and drinking water of Ufa City (Russia). The study aims at the clarification of the formation of volatile and semi-volatile chlorinated and brominated DBPs during drinking water preparation in water intakes of various types of an industrial megapolis and the discovery of the most important factors influencing their formation. Non-volatile halogenated species are also taken into consideration in the research. Since the results of over 10 years of monitoring were analyzed, it was possible to process the data using various statistical approaches.

\section{Results and Discussion}

The major halogenated SVOCs extracted from water at $\mathrm{pH} 2$ from the samples are listed in Table 1.

Table 1. Semi-volatile organic compounds regularly present in the drinking water of Ufa City.

\begin{tabular}{ccc}
\hline Name & CAS & $\begin{array}{c}\text { Characteristic Ions in the Mass } \\
\text { Spectra }(\mathrm{m} / \mathrm{z}(\text { Intensity)) }\end{array}$ \\
\hline 1-Bromopropanone-2 & $598-31-2$ & $43(100) ; 136(12) ; 138(11)$ \\
2-Methyl-4-bromobutene-1 & $20038-12-4$ & $69(100) ; 41(60) ; 55(25))$ \\
1,1-Dimethyl-3-chloropropanol-1 & $1985-88-2$ & $59(100) ; 43(71) ; 107(25)$ \\
2,3-Dichloro-2-methylbutane & $507-45-9$ & $77(100) ; 41(51) ; 76(33)$ \\
1,1,1-Trichloropropanone-2 & $918-00-3$ & $43(100) ; 125(11) ; 127(7)$ \\
2-Methyl-3-bromobutanol-2 & $2588-77-4$ & $59(100) ; 151(15) ; 153(14)$ \\
1,1-Dibromopropanone-2 & $867-54-9$ & $43(100) ; 173(64) ; 216(44)$ \\
1-Bromo-2-methylbutanol-2 & $31736-62-6$ & $73(100) ; 57(36) ; 137(29)$ \\
1,2,3-Trichloropropene-1 & $13116-57-9$ & $109(100) ; 144(20) ; 146(15)$ \\
1,3-Dibromopentane & $42474-20-4$ & $69(100) ; 149(77) ; 151(74)$ \\
1-Bromo-2,3-dichloropropane & $33037-07-9$ & $111(100) ; 75(97) ; 113(65)$ \\
1,4-Dibromopentanol-3 & $159475-15-7$ & $137(100) ; 139(92) ; 57(63)$ \\
1-Bromo-2,4-dimethylbenzene & $583-70-0$ & $105(100) ; 184(61) ; 186(60)$ \\
3,5-Dibromopentanol-2 & $1000288-19-4$ & $43(100) ; 120(56) ; 165(28)$ \\
\hline
\end{tabular}


These compounds were not detected in the samples of natural water from both water intakes. However, they were always present in the samples after chlorination. Extraction at $\mathrm{pH} 10$ did not allow the detection of other SVOCs in measurable concentrations. The levels of all the detected DBPs were measured as weight and molar units. On the basis of these measurements, the overall content of elements in semi-volatile organic products was calculated (Table 2).

Table 2. Technogenic organic carbon (TgOC), Technogenic organic chlorine (TgOCl), Technogenic organic oxygen (TgOO) and Technogenic organic bromine (TgOBr) values for trihalomethanes (THM), haloacetic acids (HAA) and semi-volatile organic compounds (SVOCs) in drinking water from surface and infiltration water intakes averaged for 2002-2019.

\begin{tabular}{|c|c|c|c|c|c|c|c|c|}
\hline \multirow{3}{*}{$\begin{array}{c}\text { Classes of } \\
\text { Disinfection } \\
\text { by-Products DBP }\end{array}$} & \multicolumn{8}{|c|}{ Value in Drinking Water } \\
\hline & \multicolumn{4}{|c|}{ Surface Intake } & \multicolumn{4}{|c|}{ Infiltration Intake } \\
\hline & $\mathrm{mg} / \mathrm{dm}^{3}$ & $\%$ & mole $/ \mathrm{dm}^{3}$ & $\%$ & $\mathrm{mg} / \mathrm{dm}^{3}$ & $\%$ & mole $/ \mathrm{dm}^{3}$ & $\%$ \\
\hline \multicolumn{9}{|c|}{ Trihalomathanes } \\
\hline$\Sigma \mathrm{C}$ in $\mathrm{THM}$ & 0.0025 & 9.6 & 0.00021 & 19.1 & 0.00049 & 7.4 & 0.000041 & 16.4 \\
\hline$\Sigma \mathrm{Cl}$ in $\mathrm{THM}$ & 0.02189 & 82.9 & 0.00062 & 56.4 & 0.0052 & 78.8 & 0.00015 & 60 \\
\hline$\Sigma \mathrm{Br}$ in $\mathrm{THM}$ & 0.00175 & 6.6 & 0.000022 & 2.0 & 0.00087 & 13.2 & 0.000011 & 4.4 \\
\hline$\Sigma \mathrm{THM}$ & 0.02614 & & 0.0011 & & 0.0066 & & 0.00025 & \\
\hline \multicolumn{9}{|c|}{ Haloacetic Acids } \\
\hline$\Sigma \mathrm{C}$ in HAA & 0.0025 & 14.5 & 0.00024 & 24 & 0.00076 & 16.9 & 0.000063 & 25.0 \\
\hline$\Sigma \mathrm{O}$ in $\mathrm{HAA}$ & 0.0033 & 19 & 0.00024 & 24 & 0.0010 & 22.2 & 0.000063 & 25.0 \\
\hline$\Sigma \mathrm{Cl}$ in $\mathrm{HAA}$ & 0.011 & 55 & 0.00031 & 31 & 0.0021 & 46.7 & 0.000059 & 23.3 \\
\hline$\Sigma \mathrm{Br}$ in HAA & 0.0018 & 9 & 0.000023 & 2.3 & 0.0006 & 13.3 & 0.0000075 & 3.0 \\
\hline$\Sigma$ HAA & 0.019 & & 0.0010 & & 0.0045 & & 0.00025 & \\
\hline \multicolumn{9}{|c|}{ Halogenated SVOC } \\
\hline TgOC & 0.0083 & 55.3 & 0.00069 & 75.8 & 0.0063 & 65.0 & 0.00052 & 81.3 \\
\hline TgOO & 0.0025 & 16.7 & 0.00015 & 16.5 & 0.0015 & 15.5 & 0.000093 & 14.5 \\
\hline $\mathrm{TgOCl}$ & 0.00069 & 4.6 & 0.000019 & 2.5 & 0.00024 & 2.4 & 0.0000067 & 1.0 \\
\hline $\mathrm{TgOBr}$ & 0.0038 & 25.3 & 0.000047 & 5.2 & 0.0017 & 17.1 & 0.000022 & 3.2 \\
\hline$\Sigma$ SVOC & 0.015 & & 0.00091 & & 0.0097 & & 0.00064 & \\
\hline
\end{tabular}

According to the obtained results, volatile DBPs (THM and HAA) were present in the analyzed samples at similar levels, while organochlorine species dominate (Table 2, Figure 1). Earlier, it was shown that chloroform, dichloro- and trichloro-acetic acids are the main products of aqueous chlorination [59-62]. According to the averaged results (2002-2019), bromine constituted about 7\% of THM in surface water intake (SW) and $13 \%$ in infiltration water intake (IW), while chlorine was $83 \%$ and $79 \%$, respectively. Bromine also constituted $9 \%$ of HAA in SW and $13 \%$ in IW, while chlorine was $55 \%$ and $47 \%$, respectively. The results are quite logical, as THM mainly forms due to haloformic reactions of HAA [63].

Nevertheless, a reverse tendency was discovered for halogenated SVOCs. The levels of organobromine SVOCs are higher than that of organochlorine ones (Table 2). In the weight units, the levels of bromine are 5.5 times higher than that of chlorine in SW and 7.0 times higher in IW. In molar concentrations, reflecting the quantity of bromine and chlorine atoms in the formed SVOC molecules in the water volume unit, $\mathrm{TgOBr}$ dominates over $\mathrm{TgOCl}$ by a factor of 2.5 for SW and 3.2 for IW. These results are confirmed by the long-term monitoring (Figure 1). Taking into account the much higher reaction rate of hypobromic acid with aromatic moieties [41] and, at the same time, its lower oxidation potential, it is possible to propose that active bromine reacts very quickly with the aromatic fragments of DOM, while active chlorine, present in much higher quantities, starts oxidizing all biological and organic molecules. Bromine remains in higher-mass species which slowly decompose further with active chlorine, producing volatile and semi-volatile halogenated DBPs. Since numerous reaction steps involving active chlorine are required to produce VOCs, the content of chlorine vs. bromine in VOCs is higher than in SVOCs. It is also worth mentioning a notable 
contribution of $\mathrm{TgOO}$ to the composition of SVOCs (14-16\%), demonstrating the decisive role of oxidative destruction in the formation of halogenated SVOCs. That conclusion can be supported by the long-term data summarized in Figures 2 and 3. Since aqueous chlorination may involve electrophilic addition, electrophilic substitution, oxidation and even radical substitution [64], direct halogenation of hydrocarbons, especially of those containing double bonds and aromatic rings, is theoretically possible. However, corresponding hydrocarbons (possible precursors) were not present in the natural water before the chlorination. Only traces of xylenes were sometimes detected. Therefore, hydrocarbons cannot be the main precursors of the organohalides listed above and the presence of the latter in chlorinated water allows for considering them as oxidative destruction products. The higher levels of organobromines of all types (Table 2) in IW samples are observed due to the higher bromide content in the infiltration water (up to $32.6 \pm 9.8 \mu \mathrm{g} / \mathrm{dm}^{3}$ in the river and up to $60.4 \pm 18.1 \mu \mathrm{g} / \mathrm{dm}^{3}$ in the wells).

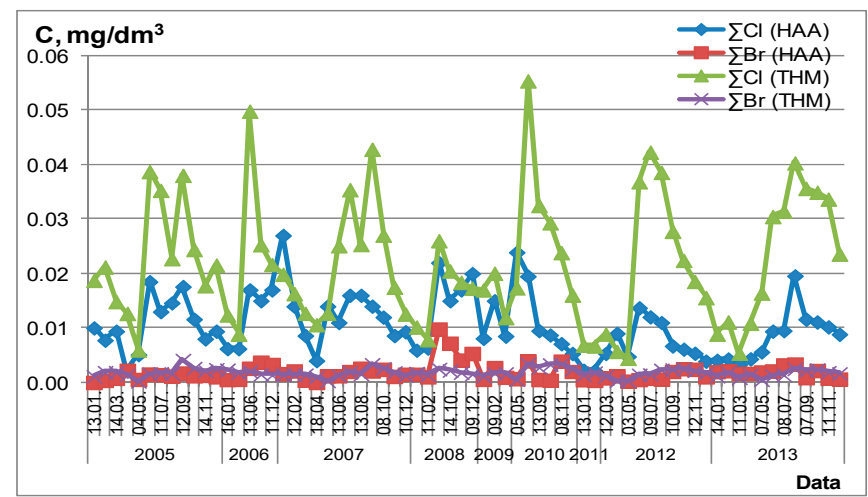

(a)

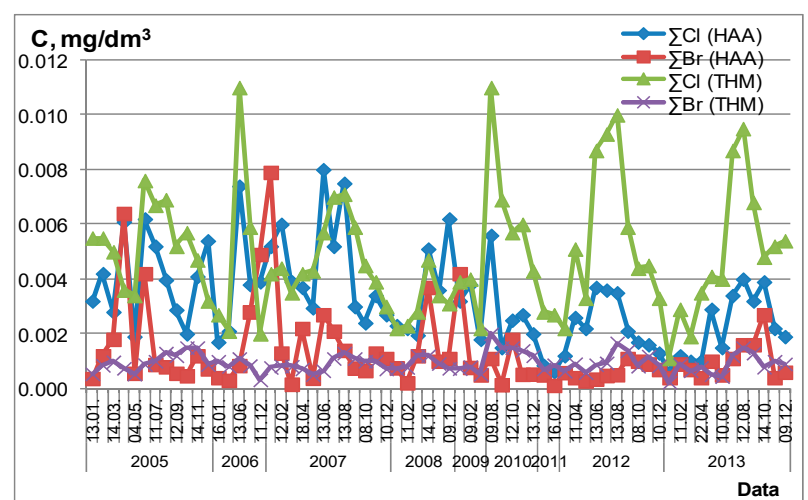

(b)

Figure 1. Integral content of chlorine and bromine in THM and HAA in the drinking water of the surface intake (a) and infiltration intake (b) in 2005-2013.

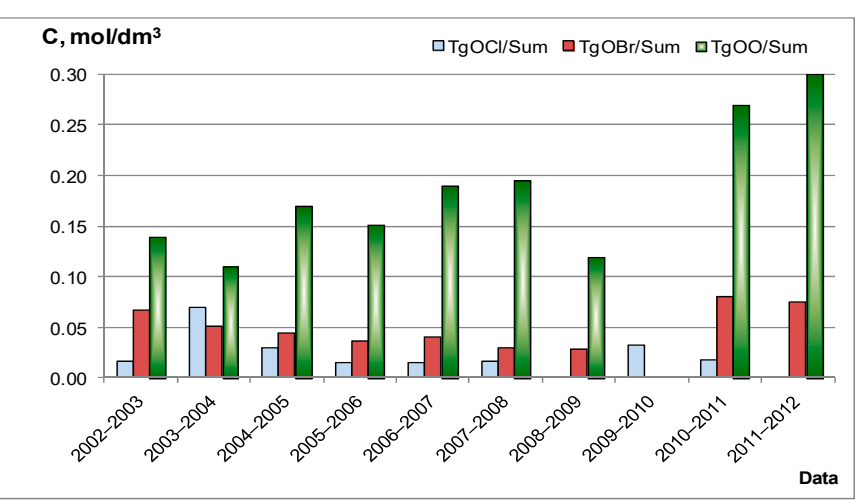

(a)

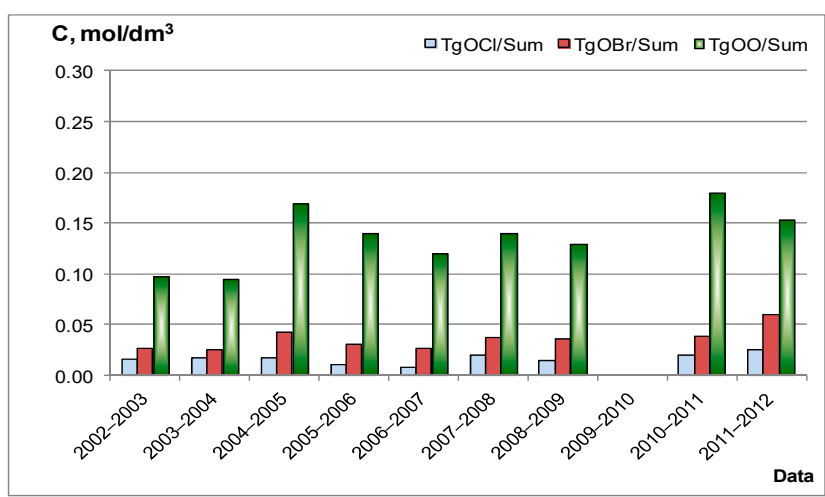

(b)

Figure 2. Annual averaged values of oxygenated, chlorinated and brominated SVOCs in total SVOCs in the drinking water of surface (a) and infiltration (b) intakes in 2002-2012. Some data are absent due to technical problems in that particular year.

To understand the dynamics of changes of brominated and chlorinated SVOCs, laboratory experiments with water samples from both intakes were conducted. River water was rather rich in DOC $\left(4.8 \mathrm{mg} / \mathrm{dm}^{3}\right)$, and for the infiltration water, that value was $0.8 \mathrm{mg} / \mathrm{dm}^{3}$. Reactions with chlorine water were carried out with various chlorine doses (1.4-6.25 mg $/ \mathrm{dm}^{3}, 4 \mathrm{~h}$ for river water and $0.5-0.85 \mathrm{mg} / \mathrm{dm}^{3}, 2 \mathrm{~h}$ for infiltration water). These parameters were close to those used at the drinking water station. Figure 4 shows the higher levels of chlorinated SVOCs over brominated ones. However, there are differences 
between SW and IW. The maximum was not reached on the curve of SW chlorination. Chlorinated SVOC levels increase constantly with time, demonstrating that the concentration of DOM is rather high and that active chlorine reacts with DOM, forming primary, secondary, tertiary, etc. products. In the case of IW, the curve demonstrating chlorinated SVOC levels passed the maximum at an active chlorine concentration of $0.58 \mathrm{mg} / \mathrm{dm}^{3}$ (Figure $4 \mathrm{~b}$ ). At that stage, the highest level of SVOCs was probably reached, while additional active chlorine only transformed SVOCs into VOCs.

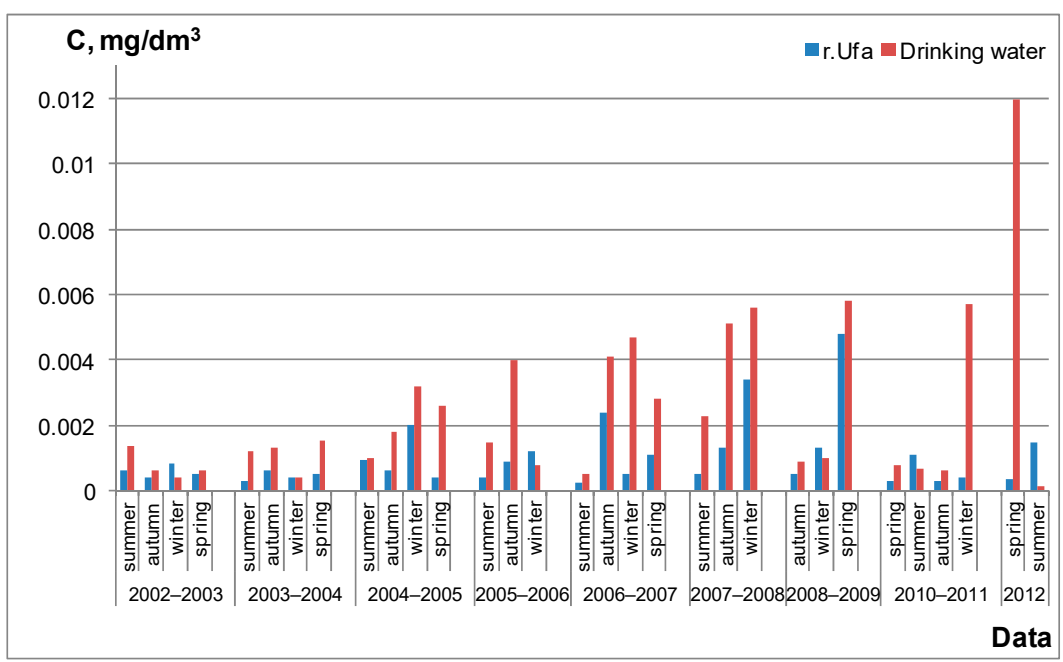

Figure 3. Seasonal values of $\mathrm{TgOO}, \mathrm{mg} / \mathrm{dm}^{3}$, in the water of the Ufa River and drinking water of SI.

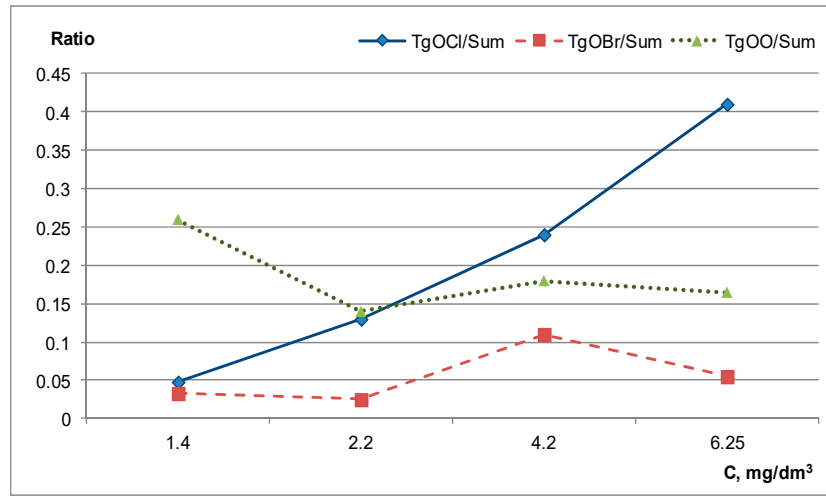

(a)

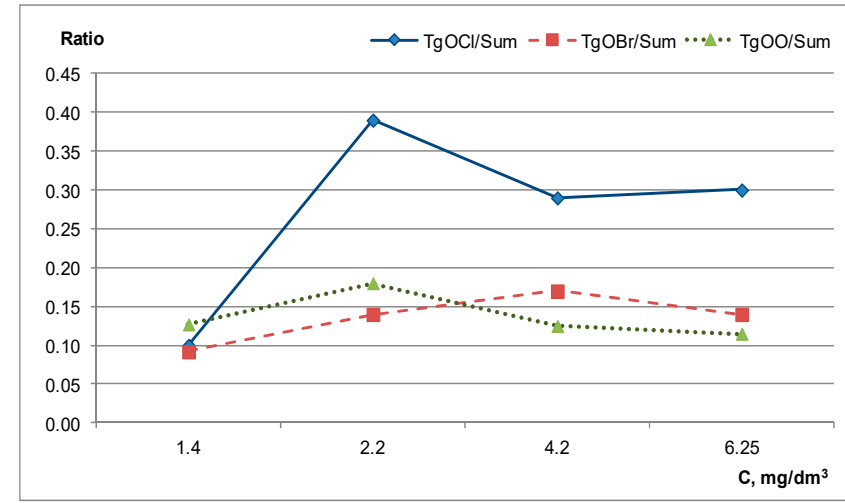

(b)

Figure 4. The ratios of chlorinated, brominated and oxygenated SVOCs in total SVOCs vs. reacted active chlorine concentration during laboratory experiments with surface water intake (SW) (a) and infiltration water intake (IW) (b).

The levels of brominated SVOCs passed the maximum for both types of water. That maximum corresponds to rather high levels of applied active chlorine. Moreover, at the initial stage of the experiment, brominated SVOCs were not detected in the experiments with river water. Most probably, all bromine present in the water and the chlorinated agent rapidly reacted with DOM, resulting in the formation of heavy non-volatile molecules, without the rupture of $\mathrm{C}-\mathrm{C}$ bonds. On the contrary, chlorine slowly reacted by mechanisms of addition, substitution or oxidation. That is why the longer reaction time results in higher $\mathrm{TgOCl}$ values. Moreover, chlorine destroys higher molecular mass compounds (including brominated ones) with formation of the corresponding SVOCs. It is possible to mention, once again, that there were more brominated species among SVOCs in infiltration water due to higher bromide levels in the wells. The lower levels of brominated SVOCs at the 
highest levels of active chlorine may involve further transformation of these compounds, formed earlier, into the volatile species.

Since bromides were not introduced in the laboratory experiments, chlorinated SVOCs dominated in the reaction mixture while, in real drinking water, brominated species dominated. This result may be also rationalized by the impossibility to reproduce the real conditions of industrial disinfection in the laboratory. For example, in laboratory experiments, there are no algae and other microflora growing in reservoirs of fresh water where chlorination takes place at the water treatment station. A notable portion of the chlorinating agent is wasted interacting with these species.

A technologically applied dose of the chlorinating agent directly depends on the quantity of microbiota and DOM. Due to higher levels of these parameters in the river water, the dose and, correspondingly, the levels of DBPs, are higher for SW. Nowadays, from the epidemiological point of view, the crucial parameter is the quantity of the remaining chlorine, rather than the dose of the chlorinating agent, as transportation of the drinking water along the distribution network should also be taken into account. However, at higher DOM levels, due to seasonal or other factors, that approach can result in increased levels of DBPs and especially halogenated SVOCs.

\subsection{Chemometric Approaches}

To find crucial factors influencing DBP formation, correlation analysis (interdependence check of each variation of two variables [65]) of the data collected over 17 years was carried out. The absence of high values of the statistically significant correlation coefficients (CCs), highlighted in Table 3, in some cases proved that not all the studied parameters demonstrated linear correlations with water quality characteristics.

Thus, VOC and SVOC types of DBPs showed quite different levels of correlation with the overall active chlorine dose: $\Sigma$ THM/chlorine dose (CC 0.64); $\Sigma \mathrm{HAA} /$ chlorine dose (CC 0.28); $\Sigma$ Hal-SVOC/chlorine dose (CC 0.15). The latter value signifies the absence of linear correlation. On the other hand, THM formation depends similarly on the primary and secondary chlorine doses (CC 0.67 and 0.51 , respectively), while HAA formation mainly depends on the secondary one (CC 0.37 and 0.59 ). Therefore, THM formation presumably involves readily oxidizable DOM moieties. On the contrary, HAA formation requires higher chlorine doses and involves less reactive fragments of DOM. Generally, the correlation between Hal-SVOC formation and active chlorine doses is weak, allowing for concluding that some other parameters of water quality may be more important. THM and HAA formation have a reasonable correlation (CC 0.55), which is quite reasonable, as HAAs are the main precursors of THM. On the contrary, a linear correlation between the levels of VOCs and SVOCs is not observed. The absence of a linear correlation between $\mathrm{SUVA}_{\text {river }}$ and $\mathrm{SUVA}_{\text {drinking water }}$ proves that aqueous chlorination is mainly the process of DOM oxidative destruction completely changing the ratio $\mathrm{A}_{254}$ / DOC.

In general, there is no direct influence of the traditional integral parameters of the natural water quality on the formation of volatile DBPs. The crucial point is the dose of the chlorinating agent and $\mathrm{A}_{254}$. The latter represents the only parameter demonstrating at least a weak correlation both for river and drinking water (Table 3, Scheme 1). Moreover, any correlations are totally absent for SVOCs. 


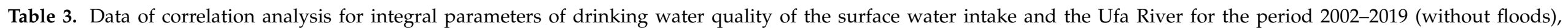
$p$-values $<0.05$. The most significant statistical correlation coefficients are highlighted.

\begin{tabular}{|c|c|c|c|c|c|c|c|c|c|c|c|c|c|c|c|}
\hline & & \multicolumn{14}{|c|}{ Drinking Water } \\
\hline & & Sum SVOC & TgOC & $\mathrm{TgOBr}$ & $\mathrm{TgOCl}$ & TgOO & $\begin{array}{l}\text { Sum } \\
\text { HAA } \\
\end{array}$ & $\mathrm{Br}$ in HAA & $\begin{array}{l}\mathrm{Cl} \text { in } \\
\mathrm{HAA}\end{array}$ & Sum THM & $\begin{array}{l}\text { Br in } \\
\text { THM }\end{array}$ & $\mathrm{Cl}$ in $\mathrm{THM}$ & DOC & $\mathbf{A}_{254}$ & SUVA \\
\hline \multirow{12}{*}{ 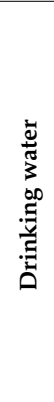 } & Sum SVOC & 1.00 & & & & & & & & & & & & & \\
\hline & $\mathrm{TgOC}$ & 0.99 & 1.00 & & & & & & & & & & & & \\
\hline & $\mathrm{TgOCl}$ & 0.72 & 0.69 & 0.80 & 1.00 & & & & & & & & & & \\
\hline & TgOO & 0.95 & 0.91 & 0.92 & 0.66 & 1.00 & & & & & & & & & \\
\hline & Sum HAA & -0.16 & -0.14 & -0.20 & -0.21 & -0.16 & 1.00 & & & & & & & & \\
\hline & $\mathrm{Br}$ in HAA & -0.18 & -0.17 & -0.18 & -0.13 & -0.18 & 0.60 & 1.00 & & & & & & & \\
\hline & $\mathrm{Cl}$ in HAA & -0.12 & -0.11 & -0.18 & -0.21 & -0.16 & 0.98 & 0.45 & 1.00 & & & & & & \\
\hline & Sum THM & -0.25 & -0.24 & -0.29 & -0.03 & -0.31 & 0.55 & 0.22 & 0.55 & 1.00 & & & & & \\
\hline & $\mathrm{Cl}$ in THM & -0.24 & -0.24 & -0.29 & -0.03 & -0.31 & 0.56 & 0.21 & 0.55 & 0.99 & 0.52 & 1.00 & & & \\
\hline & DOC & 0.03 & 0.03 & 0.2 & 0.08 & 0.02 & 0.16 & -0.13 & 0.16 & 0.40 & -0.15 & 0.43 & 1.00 & & \\
\hline & $\mathrm{A}_{254}$ & -0.23 & -0.23 & -0.24 & -0.23 & -0.22 & 0.66 & -0.19 & 0.67 & 0.84 & 0.18 & 0.85 & 0.15 & 1.00 & \\
\hline & SUVA & -0.28 & -0.27 & -0.34 & -0.40 & -0.27 & 0.07 & 0.18 & 0.02 & 0.28 & -0.05 & 0.29 & -0.50 & 0.76 & 1.00 \\
\hline \multirow{3}{*}{ 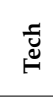 } & I dose of $\mathrm{Cl}_{2}$ & -0.13 & -0.12 & -0.14 & 0.1 & -0.20 & 0.37 & -0.04 & 0.42 & 0.67 & 0.19 & 0.68 & 0.48 & 0.44 & -0.05 \\
\hline & II dose of $\mathrm{Cl}_{2}$ & -0.21 & -0.22 & -0.19 & -0.07 & -0.18 & 0.59 & 0.15 & 0.62 & 0.51 & 0.06 & 0.52 & 0.64 & 0.67 & 0.01 \\
\hline & Sum dose of $\mathrm{Cl}_{2}$ & -0.15 & -0.14 & -0.14 & 0.03 & -0.15 & 0.28 & -0.01 & 0.30 & 0.64 & 0.18 & 0.65 & 0.65 & 0.78 & 0.12 \\
\hline \multirow{7}{*}{ 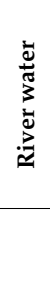 } & Turbidity & 0.01 & 0.01 & 0.01 & 0.01 & -0.02 & -0.17 & -0.15 & -0.14 & -0.28 & -0.45 & -0.28 & 0.27 & -0.24 & -0.44 \\
\hline & Chromaticity & 0.06 & 0.06 & 0.11 & 0.16 & 0.07 & 0.27 & -0.05 & 0.31 & 0.07 & -0.42 & 0.11 & 0.54 & 0.31 & -0.21 \\
\hline & Permang. index & 0.10 & 0.09 & 0.08 & 0.08 & 0.12 & 0.21 & 0.04 & 0.23 & 0.08 & 0.09 & 0.09 & 0.34 & 0.14 & -0.22 \\
\hline & COD & 0.22 & 0.21 & 0.21 & 0.12 & 0.23 & 0.08 & -0.14 & 0.12 & -0.04 & -0.41 & -0.03 & 0.11 & 0.50 & -0.15 \\
\hline & SUVA & -0.78 & -0.80 & -0.72 & -0.65 & -0.78 & 0.14 & 0.35 & 0.04 & 0.17 & -0.37 & 0.19 & -0.07 & 0.18 & 0.21 \\
\hline & & \multicolumn{8}{|c|}{ Drinking Water } & & & & & & \\
\hline & & Sum Dose of $\mathrm{Cl}_{2}$ & Turbidity & Chromaticity & Permang. Index & COD & DOC & $\mathbf{A}_{254}$ & SUVA & & & & & & \\
\hline 苋 & $\begin{array}{c}\text { I dose of } \mathrm{Cl}_{2} \\
\text { II dose of } \mathrm{Cl}_{2} \\
\text { Sum dose of } \mathrm{Cl}_{2}\end{array}$ & 1.00 & & & & & & & & & & & & & \\
\hline \multirow{7}{*}{ 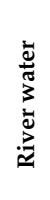 } & Turbidity & 0.09 & 1.00 & & & & & & & & & & & & \\
\hline & Chromaticity & 0.38 & 0.56 & 1.00 & & & & & & & & & & & \\
\hline & Permang. index & 0.25 & 0.24 & 0.27 & 1.00 & & & & & & & & & & \\
\hline & COD & 0.09 & 0.22 & 0.39 & 0.20 & 1.00 & & & & & & & & & \\
\hline & DOC & -0.12 & 0.24 & 0.45 & 0.06 & 0.21 & 1.00 & & & & & & & & \\
\hline & $\mathrm{A}_{254}$ & 0.54 & 0.39 & 0.94 & 0.23 & 0.87 & 0.70 & 1.00 & & & & & & & \\
\hline & SUVA & 0.38 & 0.13 & 0.52 & 0.07 & 0.42 & -0.08 & 0.62 & 1.00 & & & & & & \\
\hline
\end{tabular}

SUVA—specific ultraviolet absorption index was calculated as $\mathrm{A}_{254}$ / Total organic carbon. 


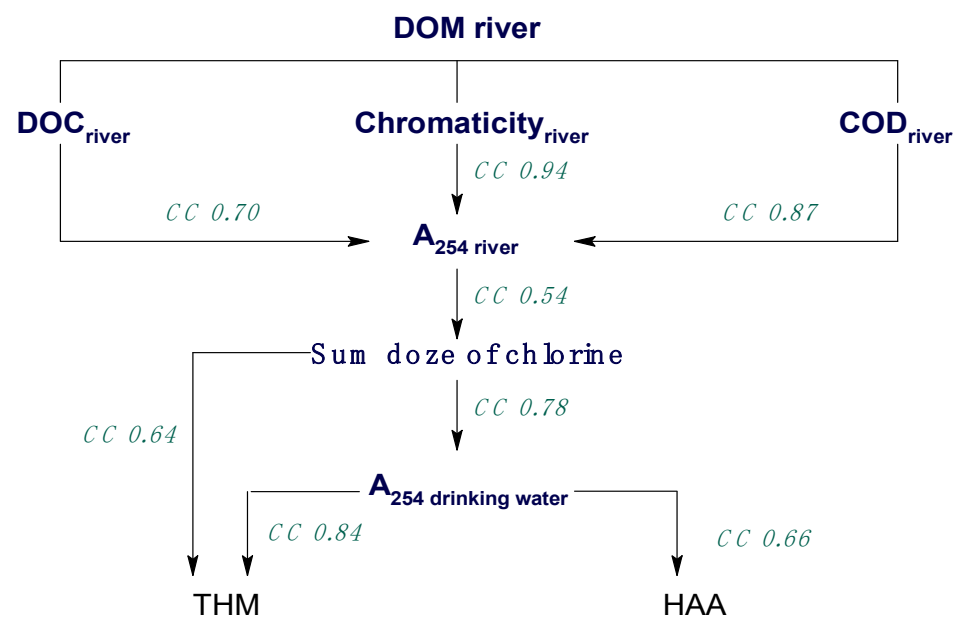

Scheme 1. Correlation between river water quality indicators, the dose of the chlorinating agent and the volatile chlorination by-products: DOM-dissolved organic matter, DOC — dissolved organic carbon, COD—chemical oxygen demand, $\mathrm{A}_{254}$ drinking water-optical density at $254 \mathrm{~nm}$, THM—trihalomethanes, HAA—haloacetic acids.

The absence of the direct correlations between THM, HAA and SUVA of the treated water was mentioned previously [53]. However, the authors emphasized that that is applicable only for natural water with low values of SUVA and UV absorption, as SUVA does not cover reactive sites in DOM responsible for the formation of DBPs. Nevertheless, studying chloroamination [66], the authors obtained linear correlations between SUVA and the formation of dichloroacetic acid (CC 0.82) and chloroform (CC 0.73), proving the decisive influence of the matrix and nature of the chlorinating agent.

Chlorine quantity in volatile DBPs ( $\Sigma \mathrm{Cl}$ in THM and HAA) notably correlates with the $\mathrm{A}_{254}$ value in drinking water (CC 0.67-0.85), and to a lesser extent with $\mathrm{A}_{254}$ value in the river water (CC $0.39-0.42)$. On the contrary, bromine quantity ( $\Sigma \mathrm{Br}$ in THM and HAA) linearly correlates only with $\mathrm{DOC}_{\text {river }}$ and $\mathrm{SUVA}_{\text {river }}(\mathrm{CC} 0.35-0.41)$. A negative correlation coefficient demonstrates that these variables are inversely proportional.

Principal component analysis (PCA) is often used in multidimensional statistical analysis $[59,67]$. It allows combining two or even more variables into a single one (factor). That combination is based on the evaluation of the dispersion of variable values around a certain value, characteristic of the new factor, resulting in the unification of the closely related variables. An application of that approach allowed clustering of the used parameters into three groups: traditional indicators of water quality, semi-volatile DBPs and volatile DBPs (Figure 5).

Therefore, the results show that the variability of VOC and SVOC levels in aqueous chlorination does not depend on a single joint factor demonstrating linear correlation with these DBP classes. The conducted analysis allowed for separating the used parameters into three groups. The first one consists of the primary and secondary chlorine doses as well as general indices of water quality. VOC levels and $\mathrm{A}_{254}$ index constitute the second group, while the third one is represented exclusively by SVOC levels. Selection of a higher or lower number of factors does not allow merging of VOCs and SVOCs into a joint group. The value of factor load was never below 0.5 . 


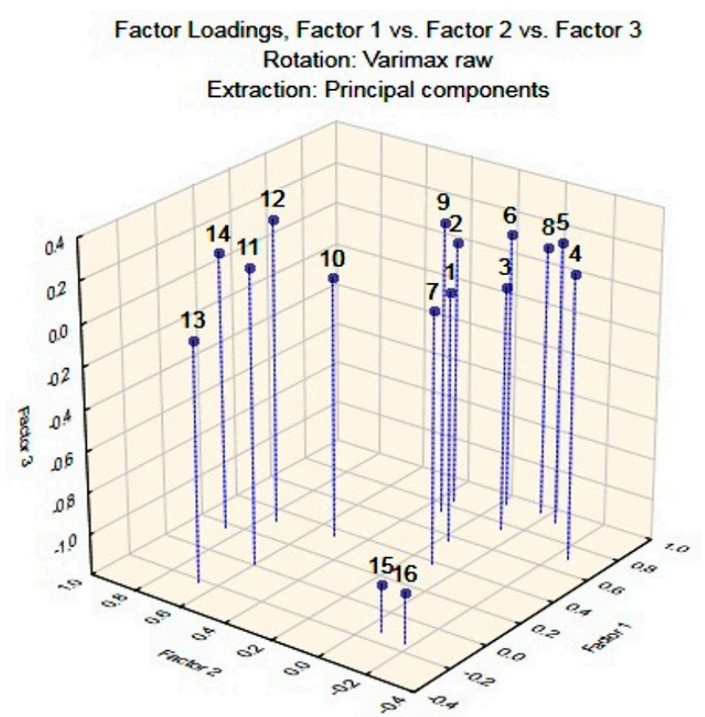

Figure 5. Results of the PCA analysis of the parameters related to the river and drinking water demonstrating three separate groups. 1. primary chlorine dose, 2. secondary chlorine dose, 3. COD (river), 4. turbidity (river), 5. color (river), 6. PMI (river), 7. DOM (river), 8. $\mathrm{A}_{254}$ (river), 9. DOC (drinking water), 10. $\mathrm{A}_{254}$ (drinking water), 11. Br level in HAA, 12. Cl level in HAA, 13. Br level in THM, 14. Cl level in THM, 15. TgOCl, 16. TgOBr.

\subsection{Seasonal Peculiarities}

All the discussed results of the correlation analysis were based on the long-term monitoring with the exception of flood periods. Correlations for chromaticity/PMI, chromaticity/COD, turbidity/PMI, turbidity/COD and COD/PMI for the Ufa River increase, while the CC for the pairs DOM/turbidity, DOM/chromaticity and DOM/PMI do not change or even decrease during floods. These results may testify that organic compounds of different natures (i.e., soil flushes with melted snow) appear in river water [68]. A major portion of organic compounds composing DOM participate in continuous biotransformation processes in water and sediments, thus, DOM represents the most reactive component of aquatic ecosystems sensitive towards any changes of the external environment [69]. Figure 6 contains the data on DOC in the Ufa River and illustrates a possible sharp change in the water quality in the flood periods of 2004-2012. Thus, in 2012, DOC significantly increased in the Ufa River water, while drinking water possessed a persistent chemical smell, which could not be eliminated by changing the reagent doses during flocculation/coagulation procedures. Nevertheless, integral parameters, including COD and PMI, did not notably increase, and the levels of THM and HAA remained at their usual values. On the contrary, the levels of halogenated SVOCs increased (Figure 7). The latter fact allows for making the conclusion that additional DOM during floods consists of heavier organic structures not so easily oxidizable with the formation of VOCs.

Another important issue involves the winter period. Stirring up of sediments, especially during freezing, plays a significant role in the formation of chlorinated SVOCs. Sharp discharges of notable water volumes from the electric power station situated upstream relative to Ufa City change the hydraulic regime of the river below the ice, resulting in stirring up of the river sediments [70]. That event results in higher levels of SVOCs and a more pronounced smell. Nevertheless, the levels of THM and HAA remain at the usual level. Higher-mass natural products from sediments may not readily form halogenated VOCs, while the levels of SVOCs and non-volatile halogenated species increase. An additional smell may be rationalized by the formation of aliphatic species with lower reactivity towards active chlorine, e.g., alcohols, aldehydes. 


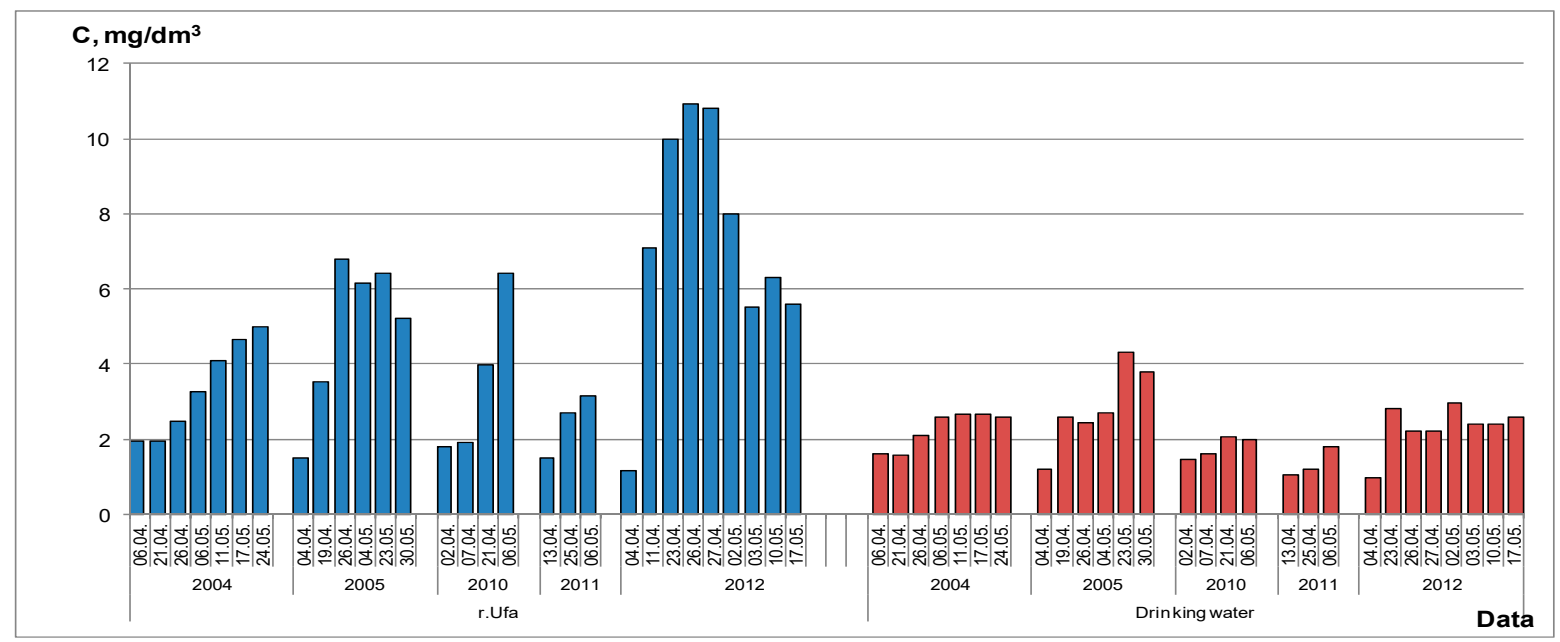

Figure 6. DOC levels in the Ufa River water and drinking SW during spring floods in 2004, 2005, 2010, $2011,2012$.

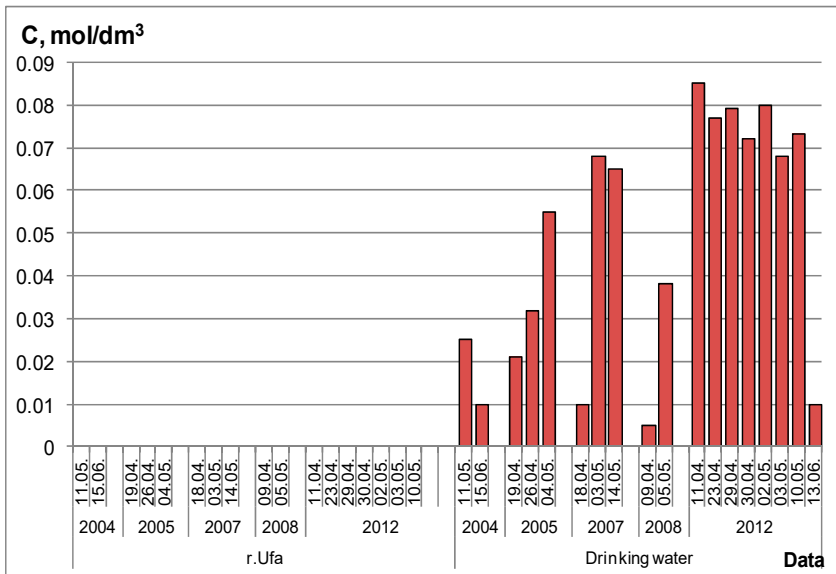

(a)

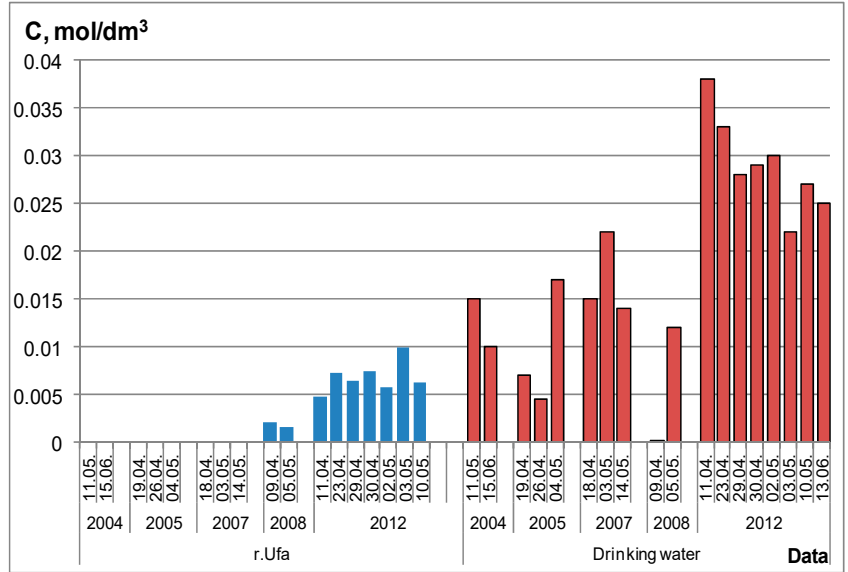

(b)

Figure 7. The ratio of $\operatorname{TgOBr}(\mathbf{a})$ and $\mathrm{TgOCl}(\mathbf{b})$ to the total SVOCs in the flood periods of 2003, 2004, 2005, 2007, $2008,2012$.

Another issue worth mentioning involves an increase in the bromine content in HAA in IW in the fall-winter period. Figure 8 illustrates corresponding results in the years when that effect was particularly pronounced. That issue may be rationalized by a higher percentage of underground water in the wells. It is highly mineralized in comparison with river water also penetrating the wells (up to $80 \%$ in summertime). The effect nicely correlates with the increase in the water hardness in these periods. River water does not demonstrate the mentioned seasonal effect.

The following calculations were conducted in order to reveal the material balance for $\mathrm{Cl}$ and $\mathrm{Br}$, present in the natural water and added with chlorinating agents vs. detected in DBPs in the averaged long-term data. The left part of the equation representing chlorine contains chlorine from the chlorinating agent and natural inorganic chlorides in the river water. The right part contains chlorine of VOCs, SVOCs, and non-volatile DBPs as well as chlorine wasted for the disinfection and inorganic chlorides in drinking water. It was impossible to separate chlorine content in non-volatile compounds and wasted in disinfection (reactions with algae, microflora, inorganic species). Thus, the value was calculated as the difference between the right and left parts of the equation. There-

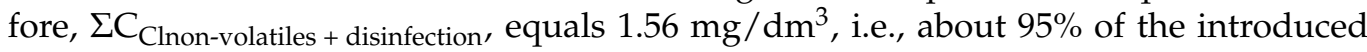
active chlorine.

$\mathrm{C}_{\text {Clchlorine agent }}+\mathrm{C}_{\text {Clriver }}=\left(\Sigma \mathrm{C}_{\mathrm{ClTHM}}+\Sigma \mathrm{C}_{\mathrm{ClHAA}}+\Sigma \mathrm{C}_{\mathrm{ClSVOC}}\right)+\Sigma \mathrm{C}_{\text {Clnon-volatiles+disinfection }}+\mathrm{C}_{\text {Cldrinking water }}$ 
$1.59+7.8=(0.0218+0.0095+0.00071)+\Sigma \mathrm{C}_{\text {Clnon-volatiles+disinfection }}+7.8$

$9.39=0.032+\Sigma \mathrm{C}_{\text {Clnon-volatiles+disinfection }}+7.8 \Rightarrow \Sigma \mathrm{C}_{\mathrm{Clnon} \text {-volatiles+disinfection }}=9.39-0.032-7.8=1.56$

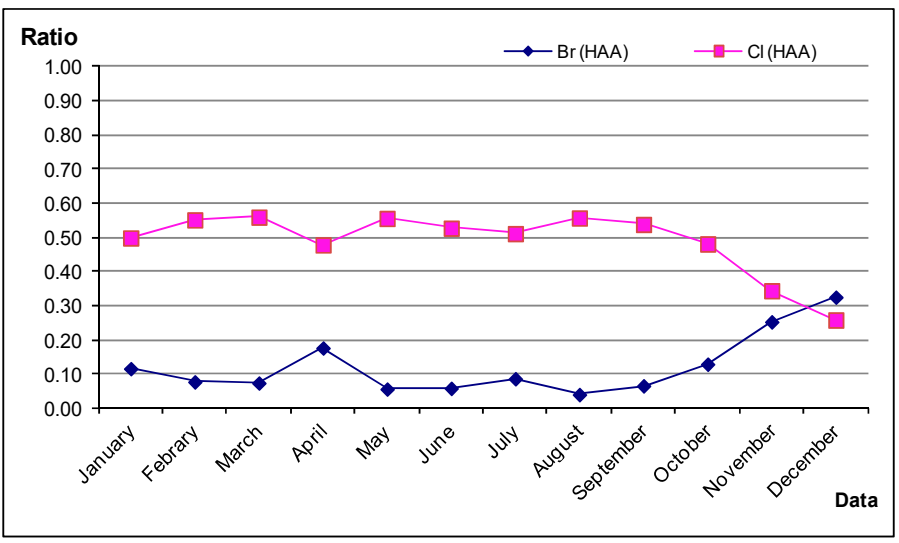

(a)

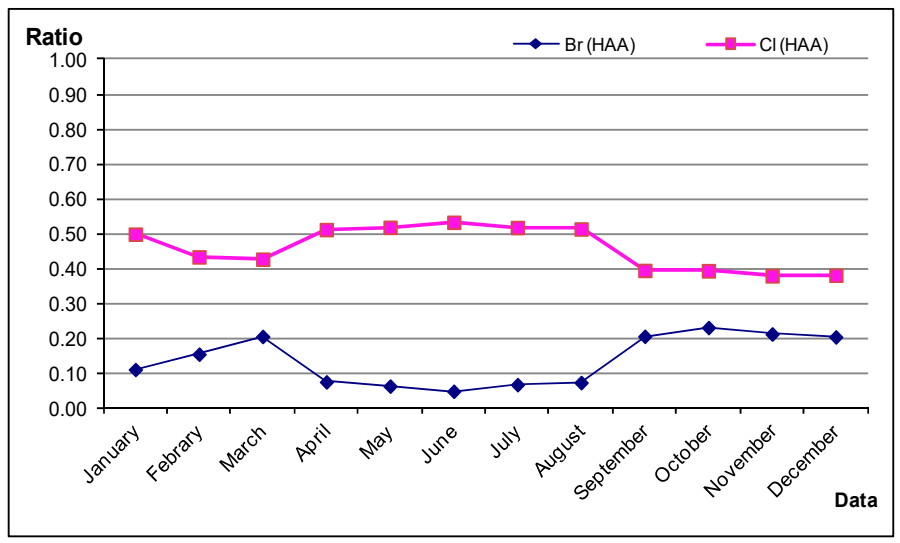

(c)

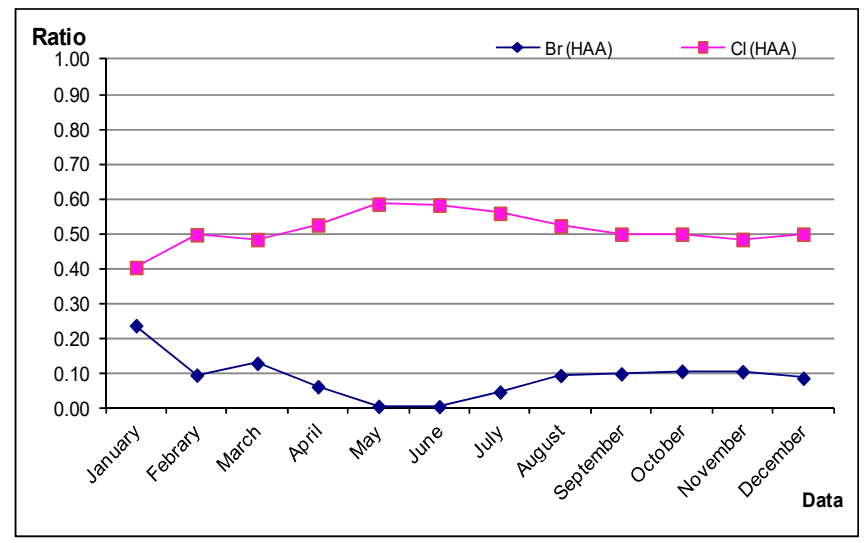

(b)

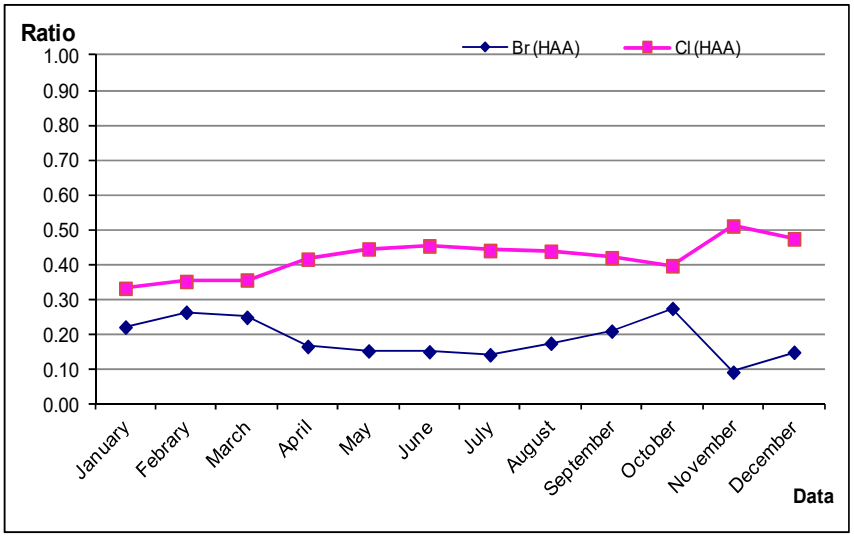

(d)

Figure 8. Relative content of $\mathrm{Br}$ and $\mathrm{Cl}$ in HAA in IW in 2006 (a), 2011 (b), 2012 (c), 2013 (d).

Material balance for bromine may be represented by the following equation, while the general quantity of bromine in the river and drinking water, as well as in the disinfecting agent, was measured with inductively coupled plasma-mass spectrometry (ICP-MS). Since bromides were not present in the drinking water, all inorganic bromine finally appeared in the brominated DOM species. It is worth mentioning that about $75 \%$ of bromine is introduced as an impurity to the chlorinating agent.

$\mathrm{C}_{\mathrm{Br} \text { in chlorinating agent }}+\mathrm{C}_{\mathrm{Br} \text { in river }}=\left(\Sigma \mathrm{C}_{\mathrm{Br} \text { in THM }}+\Sigma \mathrm{C}_{\mathrm{Br} \text { in HAA }}+\Sigma \mathrm{C}_{\mathrm{Br} \text { in SVOC }}\right)+\Sigma \mathrm{C}_{\mathrm{Br} \text { non-volatile }}$

$0.105+0.0326=(0.00174+0.0017+0.0037)+\Sigma \mathrm{C}_{\mathrm{Br} \text { non-volatile }}$

$0.138=0.00714+\Sigma \mathrm{C}_{\mathrm{Br} \text { non-volatile }} \Rightarrow \Sigma \mathrm{C}_{\mathrm{Br} \text { non-volatile }}=0.131$

The obtained value of $\Sigma \mathrm{C}_{\mathrm{Br} \text { non-volatile }}=0.131 \mathrm{mg} / \mathrm{dm}^{3}$ represents about $95 \%$ of the overall bromine introduced at the disinfection stage, meaning that in the case of complete chlorination, resulting in the full destruction of humic matter, it should appear in brominated VOC and SVOC species. 


\section{Materials and Methods}

3.1. Sampling

The following samples were collected regularly in 2002-2019:

- drinking water of the surface water intake (SW). Water comes from the Ufa River and is subjected to multistage purification including UV irradiation, primary chlorination, coagulation with aluminum sulfate, flocculation with polyacrylamide, upholding, fast filtration through filters with baked clay and secondary chlorination;

- drinking water of the infiltration water intake (IW). Water comes from the infiltration wells and is subjected only to the single-stage disinfection with molecular chlorine;

- $\quad$ water of the River Ufa before and after aqueous chlorination in the laboratory with various doses of molecular chlorine;

- water from the joint collector at the infiltration water intake (well depth $\sim 25 \mathrm{~m}$, distance $\sim 120 \mathrm{~m}$ from the river).

\subsection{Sample Preparation}

A water sample of $1 \mathrm{dm}^{3}$ was saturated with $\mathrm{NaCl}$ and subjected to extraction with dichloromethane $(1 \times 60 \mathrm{~mL})$ at $\mathrm{pH}$ 2. The extract was concentrated in a Kuderna-Danish to 1:20,000. All reagents were of high purity (Merck, Darmstadt city, Germany). Concentrated extracts were analyzed in parallel with GC-MS to identify SVOCs and gas chromatography with an atomic emission detector (GC-AED) to estimate general content of carbon-, chlorine-, and bromine-containing compounds using the proposed integrated indices of water quality.

GC-MS analysis was carried out with an Agilent 6890N-5973 instrument (Agilent, Santa Clara, CA, USA). Helium was used as a carrier gas with flow rate of $2 \mathrm{sm}^{3} / \mathrm{min}$ in split (1:5) mode, injector temperature $250^{\circ} \mathrm{C}$, capillary column HP-5MS $30 \mathrm{~m} \times 0.32 \mathrm{~mm}$ $\times 0.25 \mu \mathrm{m}$ programmed from $30{ }^{\circ} \mathrm{C}$ (the initial temperature) without isotherm to $60{ }^{\circ} \mathrm{C}$ at $20 \operatorname{grad} \times \min ^{-1}$, then to $250{ }^{\circ} \mathrm{C}$ (final temperature) at $6 \operatorname{grad} \times \min ^{-1}$. The holding time at the final temperature was $10 \mathrm{~min}$. Total analysis time was $47 \mathrm{~min}$.

Mass spectra were recorded in electron ionization mode. Ion source temperature$230{ }^{\circ} \mathrm{C}$; electron energy $-70 \mathrm{eV}$; full mass spectra were recorded in the mass range 45-600 amu, Willey 138 and NBS spectral libraries were used for the identification. The hits were accepted if the score was above 700 and further confirmed manually using the known rules of fragmentation of organic compounds [71]. Quantification was carried out using dimethylphthalate-3,4,5,6- $\mathrm{d}_{4}$ and dioctylphthalate-3,4,5,6- $\mathrm{d}_{4}$ as internal standards . The procedure resembled to some extent the US EPA 8270 method.

The applied conditions allow detecting SVOCs with Kovats indices up to 3200 on non-polar phases, covering various technogenic ecotoxicants, low and middle molecular weight products of DOM destruction. Extension of the analysis time did not allow for detecting additional organic compounds.

The GC-AED system consisted of GC HP 6890 and AED G2350A HP instruments (Agilent, Santa Clara, CA, USA). Chromatographic columns and conditions were the same as described above for GC-MS analysis. The temperature of the resonator chamber was $250{ }^{\circ} \mathrm{C}$, interface was $250{ }^{\circ} \mathrm{C}$; helium purging flow rate (purge vent) in the resonator was $35 \mathrm{sm}^{3} / \mathrm{min}$; plasma-forming helium flow rate (cavity vent) in the resonator was $60.5 \mathrm{sm}^{3} / \mathrm{min}$; nitrogen flow rate to purge spectrometer was $400 \mathrm{sm}^{3} / \mathrm{min}$; entrance oxygen pressure was 196-245 kPa, hydrogen was 63-77 kPa, methane/nitrogen mixture was $210 \mathrm{kPa}$. Quantification with GC-AED was conducted using component-independent calibration with acylbromide, bromotetradecane, 2,4,6-tribromophenol, 2-btomo-3-methylbutene-2, 3-bromo2,2-dimethylpropanol-1, 1-bromonaphthalene, 2,4-dichlorophenol, 2,4,6-trichlorophenol, $\alpha-\mathrm{HCCH}, \gamma-\mathrm{HCCH}, \mathrm{DDE}$ as standards. Processing was based on the summarized signal of all peaks on the element selective chromatograms recorded at the following wave lengths: $193 \mathrm{~nm}$ for carbon, $171 \mathrm{~nm}$ for oxygen, $479 \mathrm{~nm}$ for chlorine and $478 \mathrm{~nm}$ for bromine. A summarized signal facilitated processing of the results for the rich matrices of natural samples [72]. 
Monitoring or technological studies of water quality are generally based on comparative analysis, i.e., decrease or increase in the levels of the targeted components after some changes in the process. Considering that SVOC composition remains more or less constant for the selected water intake and water preparation technology, when carrying out comparative studies, we did not take into account isolation factors of the individual compounds used for the calculation of $\mathrm{TgOC}, \mathrm{TgOCl}, \mathrm{TgOBr}$ and $\mathrm{TgOO}$. Detection limits for these indices were as follows $\mathrm{TgOC}-1 \times 10^{-5} \mathrm{mg} / \mathrm{dm}^{3}, \mathrm{TgOCl}$ and $\mathrm{TgOBr}-$ $1 \times 10^{-6} \mathrm{mg} / \mathrm{dm}^{3}, \mathrm{TgOO}-1 \times 10^{-4} \mathrm{mg} / \mathrm{dm}^{3}$.

Quantification of HAA was conducted using gas chromatography with an electron capture detector after their methylation. The method is analogous to US EPA 552.2 and was adapted to the natural background, characteristic of the water intakes in the study. The method is validated and included in the list of the official methods of the Russian Federation (No 1.31.2011.09374).

A $1 \mathrm{~N} \mathrm{NaOH}$ solution was added to a water sample of $50 \mathrm{sm}^{3}$ to achieve $\mathrm{pH}$ 11.5. Then, methyl-tert-butyl ester was used to extract all the interfering impurities from the sample. To extract the acids, the water sample was acidified to $\mathrm{pH}<0.5$ with sulfuric acid. The addition of $3 \mathrm{~g}$ of $\mathrm{CuSO}_{4} \cdot 5 \mathrm{H}_{2} \mathrm{O}$ and $12 \mathrm{~g}$ of $\mathrm{Na}_{2} \mathrm{SO}_{4}$ was followed by energetic stirring to dissolve the salts. The targeted acids were extracted with $5 \mathrm{sm}^{3}$ of methyl-tert-butyl ester. The obtained extract was introduced into a reaction with methanol solution with $10 \%$ sulfuric acid at $50{ }^{\circ} \mathrm{C}$ for $2 \mathrm{~h}$. Then, the reaction mixture was cooled and neutralized with sodium bicarbonate. 1,2,3-Trichloropropane as an internal standard was added to a precise volume of the organic extract and the sample was injected into GC. A capillary column of medium polarity, OV-17 $(30 \mathrm{~m} \times 0.32 \mathrm{~mm} \times 0.25 \mu \mathrm{m})$, was used for the analysis. The column temperature was programmed from $50^{\circ} \mathrm{C}$ with a $14 \mathrm{~min}$ hold at this initial temperature to $145^{\circ} \mathrm{C}$ at $3 \mathrm{grad} \times \mathrm{min}^{-1}$, then to $210^{\circ} \mathrm{C}$ (final temperature) at $20 \mathrm{grad} \cdot \mathrm{min}^{-1}$.

THMs were quantified using the MEGA chromatograph and headspace approach with automatic sample preparation and HS 850 injection device (Fisons Instruments, Manchester, UK) followed by electron capture detection. An HP-624 capillary column $(30 \mathrm{~m} \times 0.25 \mathrm{~mm}$ $\times 1.4 \mu \mathrm{m}$ ) was used. The following parameters were used: sample volume- $-10 \mathrm{sm}^{3}$; time in thermostat $-15 \mathrm{~min}$ at $70{ }^{\circ} \mathrm{C}$; syringe temperature $-80^{\circ} \mathrm{C}$; injected vapor volume$1 \mathrm{sm}^{3}$; transport channel temperature- $140{ }^{\circ} \mathrm{C}$; injector temperature $-250{ }^{\circ} \mathrm{C}$; detector temperature $-300{ }^{\circ} \mathrm{C}$; column temperature $-40{ }^{\circ} \mathrm{C}(5 \mathrm{~min})$ to $180^{\circ} \mathrm{C}$ at $8 \operatorname{grad} \times \mathrm{min}^{-1}$, then to $250{ }^{\circ} \mathrm{C}(0.17 \mathrm{~min})$ at $30 \mathrm{grad} \times \mathrm{min}^{-1}$; He flow rate $2 \mathrm{sm}^{3} / \mathrm{min}$. The method is officially certified in the Russian Federation (FR. 1.31.2008.04835).

Dissolved organic carbon (DOC) was measured according to the GOST 31958-2012 method using photometry after preliminary destruction of the organic carbon with UV irradiation in the presence of $\mathrm{K}_{2} \mathrm{~S}_{2} \mathrm{O}_{8}$ as an oxidant to form carbon dioxide. The latter, penetrating through the gas membrane, was absorbed by the buffer solution of phenolphthaleine. The optical density of the solution was measured at a wavelength of $550 \mathrm{~nm}$. A standard solution of potassium hydrophthalate was used for the calibration. A water sample was made to pass through a membrane filter of $0.45 \mu \mathrm{m}$. The method is analogous to ASTM 53 and officially certified in the Russian Federation (FR. 1.31.2013.16255).

The permanganate index (PMI) was measured according to PNDF 14.1:2:4.154-99 (analog of International Method ISO 8467) after the water sample treatment with potassium permanganate during boiling in acidic media. Detection limit of the method is $0.25 \mathrm{mg} \mathrm{O} / \mathrm{dm}^{3}$.

COD was measured according to GOST 31859-2012 (analog of ISO 6060), based on the oxidation of organic compounds with potassium bichromate at elevated temperatures in acidic media. The detection limit of the method is $4 \mathrm{mg} \mathrm{O} / \mathrm{dm}^{3}$.

Optical density at $254 \mathrm{~nm}\left(\mathrm{~A}_{254}\right)$ was measured with a DR 5000 spectrophotometer (HACH, Berlin, Germany).

The specific ultraviolet absorption (SUVA) index was calculated as $\mathrm{A}_{254}$ /TOC.

Measurements of total bromine were carried out using an Aurora Elite mass spectrometer (Bruker, Bremen, Germany) with inductively coupled plasma (ICP-MS). The calibration 
curve obtained with a standard solution of $\mathrm{KBr}$ covered the range $0.001-1 \mathrm{mg} / \mathrm{dm}^{3}$. Isotope

${ }^{79} \mathrm{Br}$ was used for quantification carried out without any dilution for natural and drinking water samples and with 10-fold dilution in the case of active chlorine technical solutions. The instrument had the following parameters: RF power- $1.60 \mathrm{~kW}$, sampling depth$5.0 \mathrm{~mm}$, plasma flow-18.0 L/min, auxiliary flow- $1.65 \mathrm{~L} / \mathrm{min}$, sheath gas $-0.23 \mathrm{~L} / \mathrm{min}$, nebulizer flow- $0.80 \mathrm{~L} / \mathrm{min}$, dwell time $-50 \mathrm{~ms}$.

The statistical calculations were performed using the Statistica 10 software package [73].

\section{Conclusions}

Estimation of chlorinated and brominated DBP formation based on long-term monitoring (2002-2019) of drinking water quality from surface and infiltration intakes in Ufa (Russia) showed that the levels of volatile THM and HAA are quite similar throughout the year $( \pm 10-15 \%)$, with the prevalence of chlorinated species. Bromine level in THM in SW constitutes $\sim 7 \%$ and in IW, $13 \%$. For chlorine, these values are $83 \%$ and $79 \%$, respectively. HAAs in SW contain 9\% and in IW 13\% bromine and 55\% and $47 \%$ chlorine, respectively. However, SVOCs demonstrate a reverse trend. Brominated species (bromopropanone-2,2methyl-3-bromobutanol-2,1-bromo-2-methylbutanol-2, etc.) dominate over the chlorinated ones in the SW by a factor of 5.5 and in IW, a factor of 7 . A notable contribution of oxygen in the total composition of SVOCs (14-16\%) in both SW and IW confirms an important role of the oxidative destructive processes involving DOM during water chlorination. That process results in formation of the halogenated species from the non-volatile precursors. The levels of the dominant brominated SVOCs are higher than that of the chlorinated ones due to rather high levels of natural bromides in the natural water ( $25 \%)$ and hypobromic acid in technical disinfection reagents $(\sim 75 \%)$. That bromine rapidly reacts with DOM, forming high molecular weight brominated DOM species without breaking $\mathrm{C}-\mathrm{C}$ bonds. Actually, all available bromine penetrates organic substrates in the water disinfection conditions. Although reactions of organic matter with hypochloric acid are significantly slower, they involve the oxidation and formation of smaller organic molecules of non-volatile and semi-volatile DBPs, where bromine content is still quite high. Formation of VOCs from the original DOM, brominated DOM or SVOCs requires several additional reaction steps, including $\mathrm{C}-\mathrm{C}$ bond cleavages. In the most cases, only active chlorine is available for these processes, resulting in the higher levels of chlorine rather than bromine in THM and HAA. It is also worth mentioning that about $95 \%$ of bromine in the drinking water belongs to non-volatile DOM species.

The application of correlation analysis and PCA to the data for 2002-2019 demonstrated notable linear correlations of THM and HAA with chlorine dose and further indirect correlations with the main indices of water quality: DOM, COD, PMI in river water $\rightarrow$ optical density $\mathrm{A}_{254}$ of the river $\rightarrow$ chlorine dose $\rightarrow$ THM, HAA. Nevertheless, correlations of chlorinated and brominated THM and HAA are different. On the contrary, there is no correlation of the halogenated SVOCs with water quality parameters or chlorine dose. PCA allowed for placing these compounds into a separate group. This fact does not eliminate the possibility of the presence of some non-linear correlations. Alternatively, some crucial parameter of the water quality might not be taken into account. It could involve structural peculiarities of DOM molecules characteristic of each particular water intake. It was shown that the disturbance of sediments, changes of the hydraulic regime of the river and soil flushes during floods can result in higher formation of the brominated SVOCs due to the changes of DOM composition. However, even in these cases, the levels of HAA and THM may demonstrate their usual levels. Stability of the basic parameters of drinking water preparation and intrariver parameters over several years rationalize the stability of the DBP composition and contributions of elements to their composition.

Author Contributions: M.Y.V.—conceptualization, analytical approach development, data processing, writing a paper; A.R.K.- - application of the method of HAA analysis, collection and processing of monitoring data; I.A.M.- consulting on water quality requirements and organisation of mon- 
itoring, text approval; I.I.B.-statistical analysis; Y.S.V.- -application of chemometric approaches; E.A.K.-consulting on experimental issues, laboratory experiments; A.T.L.-general consulting and supervision of the manuscript preparation All authors have read and agreed to the published version of the manuscript.

Funding: This research received no external funding.

Institutional Review Board Statement: Not applicable.

Informed Consent Statement: Not applicable.

Data Availability Statement: The data presented in this study are available by the request to the authors.

Acknowledgments: The authors are grateful to the Core Facility Center "Arktika" of the Northern (Arctic) Federal University for the ICP-MS analysis of bromine.

Conflicts of Interest: The authors declare no conflict of interest.

Sample Availability: Samples of the compounds are not available from the authors. Any more, being totally wasted.

\section{References}

1. Cutler, D.; Miller, G. The role of public health improvements in health advances: The twentieth-century United States. Demography 2005, 42, 1-22. [CrossRef] [PubMed]

2. CDC. History of Drinking Water Treatment; US Department of Health \& Human Services; Centers for Disease Control and Prevention: Atlanta, GA, USA, 2012.

3. Bellar, T.A.; Lichtenberg, J.J.; Kroner, R.C. Occurrences of organohalides in chlorinated drinking waters. J. Am. Water Works Assoc. 1974, 66, 703-706. [CrossRef]

4. Rook, J.J. Chlorination reactions of fulvic acids in natural waters. Environ. Sci. Technol. 1977, 11, 478-482. [CrossRef]

5. Manuel, J.; Rodriguez, M.; Levallois, S.; Levallois, P. Behavior of trihalomethanes and haloacetic acids in a drinking water distribution system. Water Res. 2004, 38, 4367-4382. [CrossRef]

6. Chen, C.; Zhang, X.; Zhu, L.; Liu, Z.; He, W.; Han, H. Disinfection by-products and their precursors in a water treatment plant in North China: Seasonal changes and fraction analysis. Sci. Total Environ. 2008, 397, 140-147. [CrossRef]

7. World Health Organization. Guidelines for Drinking-Water Quality, 4th ed.; WHO: Geneva, Switzerland, 2011.

8. Sung, W.; Reilly-Matthews, B.; O'Day, D.K.; Horrigan, K. Modeling DBP Formation. J. Am. Water Works Assoc. 2005, 92, 53-63. [CrossRef]

9. Trukhanova, E.V.; Vozhdaeva, M.Y.; Kantor, L.I.; Kantor, E.A. Basic By-products Formation During Chlorination of Water Containing Humic Substances. In Proceedings of the 15th International Humic Substances Society Meeting, Book of Abstracts, Tenerife, Canary Islands, Spain, 27 June-2 July 2010; p. 67.

10. Richardson, S.D. Disinfection by-products: Formation and occurrence in drinking water. Encycl. Environ. Health 2011, 2, 110-136. [CrossRef]

11. Richardson, S.D.; Postigo, C. Discovery of New Emerging DBPs by High-Resolution Mass Spectrometry. Compr. Anal. Chem. 2016, 71, 335-356. [CrossRef]

12. Bull, R.J.; Reckhow, D.A.; Li, X.; Humpage, A.R.; Joll, C.; Hrudey, S.E. Potential carcinogenic hazards of non-regulated disinfection by-products: Haloquinones, halo-cyclopentene and cyclohexene derivatives, N-halamines, halonitriles, and heterocyclic amines. Toxicology 2011, 286, 1-19. [CrossRef]

13. Gao, J.; Proulx, F.; Rodriguez, M.J. Occurrence and spatiotemporal variability of halogenated acetaldehydes in full-scale drinking water systems. Sci. Total Environ. 2019, 323, 1-33. [CrossRef]

14. Vozhdaeva, M.Y.; Kholova, A.R.; Vagner, E.V.; Kantor, E.A.; Kantor, L.I.; Trukhanova, N.V.; Melnitsky, I.A. The use of results of expanded monitoring research for the integrated assessment of drinking water according to indices of chemical harmlessness. Hyg. Sanit. 2018, 97, 117-124. [CrossRef]

15. Richardson, S.D.; Temes, T.A. Water Analysis: Emerging Contaminants and Current Issues. Anal. Chem. 2018, 90, 398-428. [CrossRef]

16. Wong, H.K.M.; Mok, X.J. Fan Natural organic matter and formation of trihalomethanes in two water treatment processes. Desalination 2007, 210, 44-51. [CrossRef]

17. Zhang, X.; Roger, A. Minear Formation, adsorption and separation of high molecular weight disinfection by-products resulting from chlorination of aquatic humic substances. Water Res. 2006, 40, 221-230. [CrossRef] [PubMed]

18. Wei, L.L.; Zhao, Q.L.; Xue, S. Reduction of trihalomethane precursors of dissolved organic matter in the secondary effluent by advanced treatment processes. J. Hazard. Mater. 2009, 169, 1012-1021. [CrossRef]

19. Matilainen, A.; Gjessing, E.T.; Lahtinen, T.; Hed, L.; Bhatnagar, A.; Sillanpää, M. An overview of the methods used in the characterisation of natural organic matter (NOM) in relation to drinking water treatment. Chemosphere 2011, 83, 1431-1442. [CrossRef] [PubMed] 
20. Richardson, S.D. Environmental Mass Spectrometry: Emerging Contaminants and Current Issues. Anal. Chem. 2012, 84, 747-778. [CrossRef]

21. Yang, X.; Guo, W.; Shen, Q. Formation of disinfection byproducts from chlo(am)ination of algal organic matter. J. Hazard. Mater. 2011, 197, 378-388. [CrossRef]

22. Lui, Y.S.; Qiu, J.W.; Zhang, Y.L.; Wong, M.H.; Liang, Y. Algal-derived organic matter as precursors of disinfec-tion by-products and mutagens upon chlorination. Water Res. 2011, 45, 1454-1462. [CrossRef]

23. Veresmarty, C.J.; McIntyre, P.B.; Gessner, M.O.; Dudgeon, D.; Prusevich, A.; Green, P.; Glidden, S.; Bunn, S.E.; Sullivan, C.A.; Liermann, C.R.; et al. Global threats to human water security and river biodiversity. Nature 2010, 467, 7315. [CrossRef]

24. Lebedev, A.T. Mass spectrometry in the study of mechanisms of aquatic chlorination of organic substrates. Eur. J. Mass Spectrom. 2007, 13, 51-56. [CrossRef] [PubMed]

25. Kosyakov, D.S.; Ul'yanovskii, N.V.; Popov, M.S.; Latkin, T.B.; Lebedev, A.T. Halogenated fatty amides-A brand new class of disinfection byproducts. Water Res. 2017, 127, 183-190. [CrossRef] [PubMed]

26. Lebedev, A.T.; Bavkon Kralj, M.; Polyakova, O.V.; Detenchuk, E.A.; Pokryshkin, S.A.; Trebse, P. Identification of avobenzone by-products formed by various disinfectants in different types of swimming pool waters. Environ. Int. 2020, 137, 105495. [CrossRef]

27. Lebedev, A.T. Environmental Mass Spectrometry. Annu. Rev. Anal. Chem. 2013, 6, 163-189. [CrossRef]

28. Ferretti, E.; Lucentini, L.; Veschetti, E.; Bonadonna, L.; Stammati, A.; Turco, L.; Ottaviani, M. Screening and identification of unknown contaminants in water destined to human consumption: A case study. Microchem. J. 2007, 85, 57-64. [CrossRef]

29. Focazio, M.J.; Kolpin, D.W.; Barnes, K.K.; Furlong, E.T.; Meyer, M.T.; Zaugg, S.D.; Barber, L.B.; Thurman, M.E. A national reconnaissance for pharmaceuticals and otherorganic wastewater contaminants in the United States-II Untreated drinking water sources. Sci. Total Environ. 2008, 402, 201-216. [CrossRef] [PubMed]

30. Zhang, H.; Qu, J.; Liu, H.; Zhao, X. Characterization of isolated fractions of dissolved organic matter from sewage treatment plant and the related disinfection by-products formation potential. J. Hazard. Mater. 2009, 164, 1433-1438. [CrossRef]

31. Hua, G.; Reckhow, D.A. Characterization of disinfection byproduct precursors based on hydrophobicity and molecular size. Environ. Sci. Technol. 2007, 41, 3309-3315. [CrossRef]

32. Wu, L.; Zhao, X.; Zhang, M. Removal of dissolved organic matter in municipal effluent with ozonation, slow sand filtration and nanofiltration as high quality pre-treatment option for artificial groundwater recharge. Chemosphere 2011, 83, 693-699. [CrossRef]

33. Anett, G.; Annett, R.; Ulf, T.; Frank-Dieter, K. Influence of sorption to dissolved humic substances on transformation reactions of hydrophobic organic compounds in water. I Chlorination of PAHs. Environ. Sci. Technol. 2007, 41, 7003-7009. [CrossRef]

34. Lekkas, S.T.; Nikolaou, A.; Golfinopoulos, S. Structural investigations of aquatic humic substances from different watersheds. Desalination 2007, 210, 125-137. [CrossRef]

35. Lowe, J.; Hossain, M.M. Application of ultrafiltration membranes for removal of humic acid from drinking water. Desalination 2008, 218, 343-354. [CrossRef]

36. Uyguner, C.S.; Suphandag, S.A.; Kerc, A.; Bekbolet, M. Evaluation of adsorption and coagulation characteristics of humic acids preceded by alternative advanced oxidation techniques. Desalination 2007, 210, 183-193. [CrossRef]

37. Klymenko, N.A.; Kozyatnyk, I.P.; Savchyna, L.A. Removing of fulvic acids by ozonation and biological active carbon filtration. Water Res. 2010, 44, 5316-5322. [CrossRef]

38. Sun, C.; Yue, Q.; Gao, B.; Mu, R.; Liu, J.; Zhao, Y.; Yang, Z.; Xu, W. Effect of pH and shear force on flocs characteristics for humic acid removal using polyferric aluminum chloride-organic polymer dual-coagulants. Desalination 2011, 281, 243-247. [CrossRef]

39. Nawrocki, J.; Bilozor, S. Brominated oxidation by-products in drinking water treatment. J. Water SRT AQUA 1997, 46, 304-323.

40. Sun, Y.; Wu, Q.; Hu, H.; Tian, J. Effect of bromide on the formation of disinfection by-products during wastewater chlorination. Water Res. 2009, 43, 2391-2398. [CrossRef] [PubMed]

41. Zhu, X.; Zhang, X. Modeling the formation of TOCl, TOBr and TOI during chlor (am) ination of drinking water. Water Res. 2016, 96, 166-176. [CrossRef] [PubMed]

42. Navalon, S.; Alvaro, M.; Garcia, H. Carbohydrates as trihalomethanes precursors. Influence of $\mathrm{pH}$ and the presence of $\mathrm{ClL}$ and BrL on trihalomethane formation potential. Water Res. 2008, 42, 3990-4000. [CrossRef] [PubMed]

43. Liu, S.; Zhu, Z.; Qiu, Y.; Zhao, J. Effect of ferric and bromide ions on the formation and speciation of disinfection byproducts during chlorination. J. Environ. Sci. 2011, 23, 765-772. [CrossRef]

44. Inabaa, K.; Doi, T.; Isobe, N.; Yamamoto, T. Formation of bromo-substituted triclosan during chlorination by chlorine in the presence of trace levels of bromide. Water Res. 2006, 40, 2931-2937. [CrossRef] [PubMed]

45. Vasilyeva, A.I.; Vozhdaeva, M.Y.; Gagarina, L.N.; Tsypysheva, L.G.; Martynenkova, L.N.; Kantor, L.I. Sources of formation of organobromide compounds in drinking water. Post 2. Analysis of environmental objects. In Proceedings of the "V All-Russian Conference" Ecoanalytics-2000" with International Participation, Krasnodar, Russia, 17-23 September 2000; pp. $282-284$.

46. Shaydullina, G.M.; Sinikova, N.A.; Lebedev, A.T. Reaction of ortho-methoxybenzoic acid with the water disinfecting agents ozone, chlorine and sodium hypochlorite. Environ. Chem. Lett. 2005, 3, 1-5. [CrossRef]

47. Sinikova, N.A.; Shaydullina, G.M.; Lebedev, A.T. Comparison of Chlorine and Sodium Hypochlorite Activity in the Chlorination of Structural Fragments of Humic Substances in Water Using GC-MS. J. Anal. Chem. 2014, 69, 1300-1306. [CrossRef] 
48. Richardson, S.; Plewa, M.; Wagner, E.; Schoeny, R.; DeMarini, D. Occurrence, genotoxicity, and carcinogenicity of regulated and emerging disinfection by-products in drinking water: A review and roadmap for research. Mutat. Res. 2007, 636, 178-242. [CrossRef]

49. Plewa, M.J.; Simmons, J.E.; Richardson, S.D.; Wagner, E.D. Mammalian cell cytotoxicity and genotoxicity of the haloaceticacids, a major class of drinking water disinfection byproducts. Environ. Mol. Mutagen. 2010, 51, 871-878. [CrossRef] [PubMed]

50. Plewa, M.J.; Muellner, M.G.; Richardson, S.D.; Fasano, F.; Buettner, K.M.; Woo, Y.T.; McKague, A.B.; Wagne, R.E.D. Occurrence, synthesis, and mammalian cell cytotoxicity and genotoxicity of haloacetamides: An emerging class of nitrogenous drinking water disinfection by-products. Environ. Sci. Technol. 2008, 42, 955-961. [CrossRef] [PubMed]

51. Lim, M.; Snyder, S.A.; Sedlak, D.L. Use of biodegradable dissolved organic carbon (BDOC) to assess the potential for transformation of wastewater-derived contaminants in surface waters. Water Res. 2008, 42, 2943-2952. [CrossRef] [PubMed]

52. Li, Y.; Zhang, X.; Shang, C. Evaluation and improvement of total organic bromine analysis with respect to reductive property of activated carbon. Water Res. 2011, 45, 1229-1237. [CrossRef]

53. Ates, N.; Kitis, M.; Yetis, U. Formation of chlorination by-products in waters with low SUVA-Correlations with SUVA and differential UV Spectroscopy. Water Res. 2007, 41, 4139-4148. [CrossRef]

54. Liu, B.; Gu, L.; Yu, X.; Yu, G.; Zhang, H.; Xu, J. Dissolved organic nitrogen (DON) profile during back-ishing cycle of drinking water biofiltration. Sci. Total Environ. 2012, 414, 508-514. [CrossRef]

55. Muller, G. Sense or no-sense of the sum parameter for water soluble "adsorbable organic halogens" (aox) and "absorbed organic halogens" (aox-s18) for the assessment of organohalogens in sludges and sediments. Chemosphere 2003, 52, 371-379. [CrossRef]

56. Miyuake, Y.; Kato, M.; Urano, K. A method for measuring semi- and non-volatile organic halogens by combustion ion chromatography. J. Chromatogr. 2007, 1139, 63-69. [CrossRef] [PubMed]

57. Viryus, E.D.; Kapinus, E.N.; Revelsky, I.A.; Borzenko, A.G. Determination of the total content of organochlorine compounds in water based on microfluidic extraction and microculonometric analysis of the extract. Ind. Lab. 2003, 69, 3-6.

58. Vozhdaeva, M.Y.; Tsypysheva, L.G.; Kantor, L.I.; Kantor, E.A. Effect of chlorination on the composition of limited-volatile organic pollutants of water. J. Appl. Chem. 2004, 7, 952-955.

59. Rodrigues, P.; Joaquim, C.; Silva, E.; Antunes, M. Factorial analysis of the trihalomethanes formation in water disinfection using chlorine. Anal. Chim. Acta 2007, 595, 266-274. [CrossRef]

60. Lui, Y.S.; Hong, H.C.; Zheng, G.J.S.; Liang, Y. Fractionated algal organic materials as precursors of disinfection by-products and mutagens upon chlorination. J. Hazard. Mater. 2012, 209-210, 278-284. [CrossRef] [PubMed]

61. Matucha, M.; Gryndler, M.; Schröder, P.; Forczek, S.T.; Uhlî̌rová, H.; Fuksová, K.; Rohlenová, J. Chloroacetic acids—Degradation intermediates of organic matter in forest soil. Soil Biol. Biochem. 2007, 39, 382-385. [CrossRef]

62. Chu, W.; Gao, N.; Deng, Y.; Templeton, M.R.; Yin, D. Impacts of drinking water pretreatments on the formation of nitrogenous disinfection by-products. Bioresour. Technol. 2011, 102, 11161-11166. [CrossRef]

63. Pomes, M.L.; Green, W.R.; Thurman, E.M.; Orem, W.H.; Lerch, H.E. DBP formation of aquatic humic substances. J. Am. Water Works Assoc. 1999, 91, 103-115. [CrossRef]

64. Ul'yanovskii, N.V.; Kosyakov, D.S.; Varsegov, I.S.; Popov, M.S.; Lebedev, A.T. Identification of novel disinfection byproducts in pool water: Chlorination of the algaecide benzalkonium chloride. Chemosphere 2020, 239, 124801. [CrossRef]

65. Doerffel, K. Statistics in Analytical Chemistry; Adler, Y.P., Ed.; Mir: Moscow, Russia, 1994; pp. 159-164.

66. Yang, X.; Shang, C.; Lee, W.; Westerhoff, P.; Fan, C. Correlations between organic matter properties and DBP formation during chloramination. Watter Res. 2008, 42, 2329-2339. [CrossRef] [PubMed]

67. Fabbricinoa, M.; Korshin, G.V. Modelling disinfection by-products formation in bromide-containing waters. J. Hazard. Mater. 2009, 168, 782-786. [CrossRef] [PubMed]

68. Banowetz, G.M.; Whittaker, G.W.; Dierksen, K.P.; Azevedo, M.D.; Kennedy, A.C.; Griffith Stephen, M.; Steiner Jeffrey, J. Fatty acid methyl ester analysis to identify sources of soil in surface water. J Environ. Qual. 2006, 35, 133-140. [CrossRef]

69. Vozhdaeva, M.Y.; Wagner, E.V.; Cantor, L.I.; Konstantinov, A.I.; Perminova, I.V.; Cantor, E.A.; Trukhanova, N.V.; Melnitsky, I.A. Effect of Seasonal Dynamics and Chemical Treatment on the Quality of Dis-solved Organic Matter in Water Sources and Potable Water of Ufa. Mosc. Univ. Chem. Bull. 2017, 72, 154-159. [CrossRef]

70. Romanovskaya, S.L.; Kantor, L.I.; Kantor, E.A.; Khabibullin, R.R. Analysis of the total stiffness in the water source and drinking water. In Proceedings of the Ekvatek-2004, Moscow, Russia, 1-4 June 2004; p. 822.

71. Turecek, F.; McLafferty, F.W. Interpretation of Mass Spectra, 4th ed.; University Science Books: Mill Valley, CA, USA, 1993.

72. Vozhdaeva, M.Y.; Tsypysheva, L.G.; Kantor, L.I.; Kantor, E.A. Efficiency of the combination of mass-selective and atomic emission detection in chromatographic analysis of water quality. Mass Spectrom. 2005, 2, 229-236.

73. Available online: https://statistica.software.informer.com/10.0/ (accessed on 20 October 2020). 